\title{
Isolated autosomal dominant hypomagnesemia, Glaudemans type
}

INSERM

\section{Source}

INSERM. (1999). Orphanet: an online rare disease and orphan drug data base. Isolated autosomal dominant hypomagnesemia, Glaudemans type. ORPHA:199326

Isolated autosomal dominant hypomagnesemia, Glaudemans type (IADHG) is a form of familial primary hypomagnesemia (FPH, see this term), characterized by low serum magnesium $(\mathrm{Mg}$ ) values but normal urinary $\mathrm{Mg}$ values. The typical clinical features are recurrent muscle cramps, episodes of tetany, tremor, and muscle weakness, especially in distal limbs. The disease is potentially fatal. 